\title{
DET RESILIENTE LIV
}

Brad Evans \& Julian Reid

Resilient Life: The Art of Living Dangerously

Polity Press, 2014

208 sider, $\$ 24,95$

Brad Evans og Julian Reid, undersøger i deres bog Resilient Life, hvilket subjekt der skabes, når kravet om resiliens er allestedsnærværende (s. xi).

Bogens undertitel, The Art of Living Dangerously, referer til Michel Foucault, der i sin bog Biopolitikkens fødsel betegner liberalismens slagord som "lev livet farligt" (s. 65). Foucault karakteriserer dét, at mennesket opdrages i farens væsen, som en af liberalismens vigtigste følger. Evans og Reid, henholdsvis er lektor ved Bristol Universitet og professor ved Lapland Universitet, begge i internationale relationer, viderefører dette tankegods og undersøger, hvilket menneske der opdrages, når farens væsen er total, og når subjektiveringen betinges af den resiliente ideologi?

Evans og Reids ambition er tofoldig: De vil for det første levere den første substantielle politiske kritik af konceptet resiliens (s. xi). For det andet vil de revitalisere den kollektive forestillingsevne (s. 201) og anlægge byggestenene til en poetisk subjektivitet (s. 193). Den poetiske subjektivitet forholder sig modsat den resiliente subjektivitet, hverken apolitisk eller nihilistisk til sin eksistens (s. 37).

Evans og Reid indleder med at analysere udviklingen fra sikkerhed til resiliens. Resiliens er ifølge dem en ny dominerende mentalitet i den nuværende neoliberale regeringskunst. Resiliens må ifølge Evans og Reid analyseres, hvis vi ønsker at forstå den neoliberale magtudøvelse.

Resiliens defineres fra officielle kilder, her FN's klimapanel (IPCC), som et systems "evne til at anticipere, absorbere, rumme, eller komme sig over effekterne af en potentiel skadelig begivenhed på en rettidig og effektiv facon, og samtidig sikre bevarelsen, retableringen, eller forbedringen af dets essentielle basale strukturer og funktioner" (s. 6). Resiliens defineres af FN også som et systems kapacitet til at tilpasse sig, modstå eller ændre sig ved eksponering for faremomenter (s. 71). Disse to definitioner eksemplificerer, hvordan fortalere for resiliens definerer begrebet. Som bogen skrider frem er det interessant at bemærke, at det er virkningen af resiliens, der er det centrale stridspunkt. Selve definitionerne er fortalere som kritikere enige om. 
Udviklingen fra sikkerhed til resiliens viser, hvorledes liberalismen tidligere bestræbte sig på at sikre mennesket og samfundet fra trusler, risici og ødelæggelse. Derimod bestræber de nutidige neoliberale regimer sig på at gøre mennesket og samfundene frie $t i l$ at omfavne og se potentialerne i det faretruende. Ifølge Evans og Reid anskuer resiliensideologien risici og farer som uundgåelig og produktiv for menneskets udvikling. Det resiliente subjekt er et selv-eksponerende subjekt. Med skiftet fra sikkerhed til resiliens er vi ifølge Evans og Reid indtrådt i ny politisk æra (s. 1-2).

Evans og Reids biopolitiske analyse af resiliens informerer om liberalismens egen modstandsdygtighed - det vil sige dens evne til at genopfinde sig selv: Liberalismen altid har taget livet som sin principielle referent for sine politikker, hvilket har muliggjort sondringer mellem produktive og uproduktive liv (s. 38). Det er livet, der medierer horisonterne mellem den liberale tanke og praksis, ikke økonomien (s. 66). Liberalismen er stadig allieret med livsvidenskaberne; den foretrukne allierede er nu livsvidenskaberne om resiliens.

Ifølge Evans og Reids cementerer opkomsten af resiliens udviklingen fra liberalisme og neoliberalisme. De hævder, at mens biopolitikken i den tidligere liberalisme havde beskyttelsen af befolkningen som sit primære styringsobjekt, så gør biopolitikken i de nutidige neoliberale regimer krav på at beskytte al liv i biosfæren (s. 44). Og hvor liberalismen eksempelvis sammenholdt profitskabelse med befolkningens sikkerhed, så udvider neoliberalismen profitskabelsen til også at omhandle vareliggørelsen og ejerskabet af biosfæren (s. 76).

Evans og Reid analyserer den subjektivitet, der skabes af den resiliente indstilling og ideologi, hvad enten det er inden for felter som arkitektur, psykologi, samfundsvidenskab eller udviklingshjælp og bæredygtighed. Det resiliente liv undersøges ved dets resonans med tematikker såsom katastrofer, politisk hukommelsestab, overlevelsesevnen, velfærdsstaten, opkobling og det posthumane teknologisk forbundene subjekt, tilpasningsevnen, samt biologi og det biologiske liv (s. 20-68).

Evans og Reids omfangsrige analyse leder dem frem til at karakterisere det resiliente subjekt som både legemliggørelsen af en neoliberal subjektivitet og indoptagelsen af ren biologisk fornuft, hvor mennesket reduceres til en organisme, der blot kan tilpasse sig (s. 43, 60, 63). Det resiliente subjekt omfavner udsættelsen for risici som et privat gode, det har opgivet troen på sikkerhed, og det accepterer den konstante tilpasning til farer som livets vilkår. Subjektet møder verden som et nødvendigvis farligt sted med katastrofale følger i livet (s. 41-42, 63). Det resiliente subjekt er en tosidet 
størrelse, der rummer både den biologiske reduktion af menneskets livskapaciteter og omfavnelsen af afpolitiserende økonomiske nødvendigheder (s. 6, 37).

Evans og Reids kritik af den resiliente ideologi danner afsæt for bestemmelsen af det mest fundamentale problem: Resiliens "fornægter os muligheden for at tænke poetisk" (s. 63). Der opstår altså en mulighed, eller nødvendighed om man vil, for at formulere en radikal anden tilværelse. Evans og Reid vil skabe en meningsfuld menneskelig eksistens, ved at revitalisere den kollektive forestillingsevne gennem formuleringen af, hvad de kalder, den poetiske subjektivitet (s. 201). Fundamentet til denne subjektivitet bliver lagt i bogens sidste tre kapitler.

Denne poetiske subjektivitets første bestemmelse er, at mennesket må tænkes som atmosfærisk-æstetisk-affektiv irreducibel (s. 126). Den poetiske subjektivitet er startskuddet til en ny etik, der har som sit mål at berige mennesket i dets atmosfæriske-æstetiske-affektive register (s. 137, 193). Det fremgår således, at den poetiske subjektivitet er meget mere end blot en politisk subjektivitet. Evans og Reid vil skabe et reelt bæredygtigt atmosfærisk-æstetisk-affektiv liv. Det være sig et liv, hvor vi ikke frygter for vores handlen i de rum og atmosfærer, vi bevæger os i. Tænk blot på klimakrisen, og de forhold vi har skabt for vores natur, hvor vi ligefrem dør af forurening. Det være sig også et liv, hvor vi ser skønheden i og omkring os selv, hinanden og verdenen. I det poetiske liv er mennesket ikke er bange for, hvem det er, og hvad det kan udrette. Det frygter ikke dets egne følelser og handlinger.

Evans og Reid formulerer ikke nogen endelige mål for den poetiske subjektivitet. I stedet peger de særligt i bogens afsluttende kapitel på, hvad man kan kalde zoner, erfaringer og scener, hvori den poetiske subjektivitet træder frem. Det være sig bl.a. i Lars Von Triers Antichrist, hvor hovedpersonen Justine legemliggør den poetiske subjektivitet. Modsat søsteren Claire der legemliggør den resiliente subjektivitet (s. 179, 189). Den poetiske indstilling finder de også i receptionen af Cormac McCarthys The Road (s. 157) eller i Samuel Becketts skuespil Endgame (s. 142). Der er også eksempler på den poetiske subjektivitet fra billedkunsten, filmkunsten, pædagogikken og filosofien (bl.a. de antikke grækere, Kant, Deleuze og Sloterdijk).

Der er dog en række forhold man savner at Evans og Reid beskæftiger sig med. De kunne med fordel supplere bestemmelsen af den poetiske subjektivitet med mere pædagogiske eksempler. Desuden mangler der eksempler på, hvornår den re- 
siliente magtudøvelse ikke lykkes. Ifølge Foucault er der altid noget, der undslipper magten. Endelig kan man savne et bud på, hvordan det trods resiliensideologiens udbredelse er muligt for subjektet at forme sig selv.

Man kan også pege på nogle teoretiske forhold, der kunne være uddybet. Hvordan har begrebet biopolitik udviklet sig siden Foucault og hvilke begrænsninger rummer dette? Hvordan påvirker forskellige typer af neoliberalisme resiliensideologien på forskellig vis? Og hvilke andre styringsmentaliteter end biopolitikken, liberalismen og neoliberalismen påvirker resiliensideologien?

Det er Evans og Reid fortjeneste, at de operationaliserer Foucault på fænomenet resiliens ved hjælp af begrebet biopolitik og således opdaterer biopolitikkens samtidige karakteristika: Mennesket subjektiveres gennem resiliensforanstaltninger, ikke traditionelle liberale sikkerhedsforanstaltninger. Hele biosfæren er biopolitikkens regeringsgenstand, ikke blot befolkningerne osv.. Resilient Life bidrager på denne vis med en udbygning af sikkerhedsforskningen, hvor særligt sikkerhedens problematikker sættes på spil.

Sammenlignet med andre kritikker af den liberale magtudøvelse, så tilbyder Resilient Life ydermere et nyt magtanalytisk fokus forankret i, hvad man kan kalde homo resilio, fremfor det fortærskede homo economicus. Homo resilio (resiliens er afledt af det latiske resilio) er et nyt subjekt med sin egen dynamik. Undersøgelsen af dette subjekt skal ikke blot udspille sig på økonomiens domæne, men må medtage miljøog bæredygtighedspraksisser. Det er bogens analytiske fortjeneste at bane vejen for, at andre kan følge samme magtanalyse forankret i homo resilios virke.

\section{Kristian Bisgaard Haug}

